Media Industries $7.1(2020)$

\title{
Media Industries in Global Frames: Craft, Collaboration, Competition-Introduction
}

\author{
Darrell William Davis ${ }^{1}$ \\ LINGNAN UNIVERSITY \\ Ddavis [AT] ln.edu.hk
}

This special section grew from a colloquium "Media Industries in Global Frames: Craft, Collaboration, Competition" and a master class at Lingnan University, Hong Kong, in May 2018. At both events, scholars and graduate students shared thoughts, tools, and contemporary vagaries on media industries in global frames. They were asked to reflect on craft, collaboration, competition, and the research that these three keywords opened in line with problems and their diagnosis in various media industries. Details of the events can be viewed at: https://www.ln.edu.hk/ccs/conference.html\#colloquium.

Craft, collaboration, and competition have reach into the range of media industry production, circulation, and research. These keywords are loaded terms, dependent on specific contexts for meaning, and connotations. All three have radically labile senses, prone to change and sensitive to circumstances. All three are Janus-faced, indicating positive and negative, exemplary and culpable activities. These keywords define the practices of the global media industries and in turn illuminate the operations of media industries at their best, and worst.

Craft lately has taken on artisan connotations, in departure from the bland, automated sameness of mass production. For example, "Hollywood craft" has a tangible link to well-wrought, coolly executed films of integrity, ambition, and sincerity. Disney Pixar's Coco "is the kind of disciplined craft writers respect and aspire to," claims Variety (November 2017). Another term, "tele craft," could name the current Golden Age of customized, user-sensitive caches of mobile televisual resources. The same goes for craft beers, coffee, oils, sausages, and many more products whose taste had been bleached out by mechanical production, scale, and automation. The "craft" prefix signals not just quality, but personality and sincerity endowed in the product by a caring maker. So in this sense, Marvel blockbusters may be further away from craft entertainment because of their massive scale, than the Coen brothers, Greta Gerwig, and many others with their strong personal visions. In specific sectors of any given media industry, craft addresses the nuts-and-bolts of media assemblage, examining local conventions, heuristics, and communities. In global, transnational production, 
however, local conventions of craft are often under pressure by coproduction requirements; the interests of financiers are likely to override the craft know-how of experienced filmmakers. Pawanpreet Kaur's essay on Mumbai stunt workers illustrates this friction very well.

Collaboration in wartime is helping the enemy and undermining the good fight. Collaboration in peacetime is more benign, although its true import is contingent, labile, subject to renegotiation, and all-too-familiar urges to seize, rather than share. Collaboration in media industry is foundational, and the whole ecology of film and television production depends on collaborative exchange, trust, and sharing of information and talents. This is especially salient in media industries framed by capital flows and digital connectivity. However, collaboration is not without risk, and demands platforms of ethical authentication, and fair distribution of responsibility and reward. The ethical dimensions of collaboration are manifold, and complex, depending on specifics of collaborative exchange, whether in small workshops, startups, or multinational firms.

Competition, in its best behavior, promotes excellence and productivity, when governed by organized and regulated contest, as in sporting events. But when rules are not followed, competition becomes cheating as seen in extended disputes between companies and nations engaging in "trade wars." In media industries, there is surfeit of competition, within and between sectors. Think of the demise of Blockbuster and the rise of Netflix: in the distribution of entertainment, a new business model drives out the old. Similarly, Nobuko Kawashima in our current section analyzes the contending business models in Japanese media industries, concluding that their traditional forms are now on the wane, and new business models surfaced to stimulate purchases of media products. Perhaps the most familiar case study on competition in media industries is the reactions from several regional sectors to the dominance of American media since the 1950s. Michael Curtin's essay shows how American media's hegemony has been challenged by media players from different areas, who aspired to compete for market share and influence in the globalized marketplace. Curtin's essay further indicates that competition's positive valence is under strain when big companies consolidate, as behemoths arise, with broadcast, theatrical, digital, publishing, recording, talent, and other sectors under one roof. This tendency to gigantic conglomeration creates uncertainty, for consumers, suppliers, and regulators. Large-scale merger and acquisitions must also answer to national security regulation, which is supposed to protect domestic trade from foreign encroachment and manipulation.

Collaboration and competition can be seen as twin concepts; they form a dialectical relation, sometimes cognate, sometimes dissonant. Business competitors form alliances with one another, and then they become collaborators, hoping to reduce the cost of fierce competition. Sometimes, the alliance is simply a technology transfer in exchange for a share of the market. Erica Poon's piece discusses the ways Shaw Brothers studio adapted Japanese pictures, their competitors, to Chinese tastes, with mixed results. In her essay, competition works via collaboration, in that Shaws wanted to measure up to Japanese studios, learn from them, and compete at film festivals.

In our selection of essays, we chose seasoned researchers and young scholars to publish work delivered at our events in Hong Kong. Michael Curtin's "Post Americana: Twenty-First Century Media Globalization" probes contemporary mediascapes in a globalized environment where American products are as popular as ever, although their underlying business 
models are at risk, from challenges and competitors around the world. Contrary to homogenization anxieties, the Pax Americana has stimulated arrays of locally specific alternatives that have won market share and influence at American expense. The media on offer today upends cultural hierarchies, as well as spatial boundaries, to the extent that global leadership itself seems oddly improbable and unlikely. Still, the infrastructures and institutions of media production remain globally interconnected, thanks to capitalist apparatus. This capitalist infrastructure is both American and global, with technological exceptions challenging (not proving) regulatory rules. As American media becomes more embedded, post-American formations arise.

In "Business Models of the Media Industries-A New Direction?" Nobuko Kawashima singles out online media circulation as the main culprit in subverting the advertising and subscriber models of funding and revenue. Where media industries traditionally supplied entertainment to hungry audiences, building in big margins to profit owners, digital media engineers a reversal: using big data to quantify and track consumer tides. She goes as far as to call the new financial arena "market failure," not merely disruption or radical change. By the standards and scale of twentieth-century Japanese media, it may appear that recent upheavals in media packaging and consumption are indeed a failure, but Kawashima goes on to detail at least five new models of media industry, using Japanese pop music and journalism as instructive examples.

In another piece, we learn about division of labor in Mumbai. There are different roles, sometimes harrowing, played in media industry work. Ethnographic descriptions abound in "Race, Labor, and Resistance among Bollywood Stunt Workers," which targets one of the most arresting jobs in media industries: the Mumbai stunt worker, who blends choreographic, narrative, and dynamic trompe-l'oeil feats of bodily risk. Pawanpreet Kaur aptly covers issues of creativity, training, pride, and community in the guilds and factions working in this key sector. While acknowledging increasing uses of digital interventions in stunt work, Kaur focuses on the threats of foreign interlopers in a trade (and close-knit community) that is well established.

Finally, there is Erica Poon's essay on "Crafting a World-Class Brand: Shaw Brothers' Appropriation of Foreign Models." She analyzes Shaw Brothers' intent to go global in the 1960s, aspiring to the benchmark set by Hollywood. Something of a control fiend, Run Run Shaw used everything he could grasp-talent pools, narratives, management tools, and marketing efforts. He expanded its talent to employ Japanese filmmakers who were imported to remake their signature films from the 1950s, for Chinese and Southeast Asian audiences. This was an efficient way to raise output, enhance variety, and appeal to a broader audience base. This audience was the postwar generation making a new life in Hong Kong. But while it raised efficiency and product quantity, it did not quite lift Shaw Brothers to the level of Japanese studios or to Hollywood. This was a case of using foreign technicians and blueprints, but not raising the prestige of the whole brand.

Craft, collaboration, and competition all have common element: struggle. Struggle with craft is about solving knotty problems in design, prototypes, and supply chains. Collaboration, like competition, brings struggle with other people, in negotiation, compromise, and prioritization. It is a contentious process. Media industries of the twenty-first century are accelerating, and competition may hold sway in our thinking about economic struggle, though 
collaboration may be imminent, bringing amelioration of the ruthlessness that glorifies only victorious players. This zero-sum is somehow atavistic, even as our worlds rush headlong into unexpected collectivities of machine-enhanced disruption.

When you read the different glosses on our keywords-craft, collaboration, competitionyou are seeing traces of our event in 2018. In hindsight, it appears as a most serene and orderly occasion, long before more recent outbreaks of anarchy, chaos, and pandemic in Hong Kong.

${ }^{1}$ Darrell William Davis is Honorary Professor in Visual Studies, Lingnan University. He studied American film industry with Tino Balio, at Wisconsin. With David Bordwell he completed his PhD in Japanese cinema. He has written books and articles on screen industries in the Asia Pacific region, such as East Asian Screen Industries (BFI, 2008), and "Marketization, Hollywood, Global China" in Modern Chinese Literature and Culture (Spring 2014) and "Questioning Diaspora: Mobility, Mutation and Historiography in the Shaw Brothers Film Studio," in Chinese Journal of Communication (2011). 